\title{
A phase I dose-escalation study of MEDI-575, a PDGFR $\alpha$ monoclonal antibody, in adults with advanced solid tumors
}

\author{
Carlos R. Becerra $\cdot$ Paul Conkling $\cdot$ Nicholas Vogelzang $\cdot$ Hilary Wu \\ Shengyan Hong $\cdot$ Rajesh Narwal $\cdot$ Meina Liang $\cdot$ Fatemeh Tavakkoli $\cdot$ \\ Naimish Pandya
}

Received: 25 June 2014 / Accepted: 4 August 2014 / Published online: 23 August 2014

(C) The Author(s) 2014. This article is published with open access at Springerlink.com

\begin{abstract}
Purpose The purpose of the study was to evaluate safety and determine the maximum tolerated dose (MTD) of MEDI-575, a fully human monoclonal antibody that selectively binds to platelet-derived growth factor receptor- $\alpha$ (PDGFR $\alpha$ ), in patients with advanced solid tumors.

Methods This phase I multicenter, open-label, single-arm study enrolled adults in a $3+3$ dose escalation design to receive MEDI-575 (3, 6, 9, 12, or $15 \mathrm{mg} / \mathrm{kg})$ once weekly (QW) until toxicity or disease progression occurred. One $0.5-\mathrm{mg} / \mathrm{kg}$ dose was given before the first dose in the 3-mg/ $\mathrm{kg}$ cohort to determine pharmacokinetics (PK) and pharmacodynamics under unsaturated conditions. After completion of dose escalation in the QW cohorts, patients were enrolled in two additional cohorts and received MEDI-575 25 or $35 \mathrm{mg} / \mathrm{kg}$ every 3 weeks (Q3W). Secondary measures included assessments of PK, immunogenicity, and antitumor activity.
\end{abstract}

\author{
C. R. Becerra $(\bowtie)$ \\ Sammons Cancer Center, Texas Oncology P.A., 3410 Worth St., \\ Suite 300, Dallas, TX 75246, USA \\ e-mail: Carlos.Becerra@usoncology.com \\ P. Conkling \\ Virginia Oncology Associates, Norfolk, VA, USA \\ N. Vogelzang \\ Comprehensive Cancer Center of Nevada, Las Vegas, NV, USA \\ H. Wu \\ IU Health Central Indiana Cancer Centers, Indianapolis, IN, USA \\ S. Hong $\cdot$ R. Narwal $\cdot$ M. Liang $\cdot$ N. Pandya \\ MedImmune, Gaithersburg, MD, USA \\ F. Tavakkoli \\ University of Maryland, Baltimore, MD, USA
}

Results A total of 35 patients received MEDI-575 QW $(n=23)$ or Q3W $(n=12)$. Most treatment-related adverse events were grade 1 or 2 in severity across all dose levels, with fatigue $(n=12)$ and nausea $(n=8)$ being reported most frequently. With no reports of dose-limiting toxicities (DLTs), the MTD was not reached. MEDI-575 exhibited a nonlinear PK profile and increased plasma platelet-derived growth factor-AA levels in a dose-dependent manner with limited immunogenicity. Stable disease was reported as the best tumor response in 9 of 29 evaluable patients; however, no objective responses were reported.

Conclusion Administration of MEDI-575 QW or Q3W resulted in a favorable safety profile, including a lack of DLTs, but without evidence of antitumor activity in patients with refractory solid tumors.

Keywords Receptor Platelet - Platelet-derived growth factor alpha $\cdot$ Neoplasms $\cdot$ Clinical trial, phase I

\section{Introduction}

Platelet-derived growth factors (PDGFs) are peptide growth factors that stimulate cellular growth, proliferation, and differentiation, through transmembrane receptor tyrosine kinases PDGF receptor alpha (PDGFR $\alpha$ ) and $\operatorname{PDGF}$ receptor beta (PDGFR $\beta$ ) [1]. Inhibition of $\mathrm{PDGFR} \alpha$ signaling has been used as an effective therapeutic strategy in diseases wherein such signaling is known to be important for tumor progression. For example, imatinib mesylate, a tyrosine kinase inhibitor with activity against $\operatorname{PDGFR} \alpha$, has been associated with a high response rate in patients with chronic eosinophilic leukemia [2], in which an FIPILI 1-PDGFR $\alpha$ fusion leads to aberrant activation of PDGFR $\alpha$ in eosinophils and other hematopoietic precursors [3]. 
Targeting PDGFR $\alpha$ in the stromal compartment, particularly in the lung, may have therapeutic potential for inhibition of tumor growth $[4,5]$.

MEDI-575 is an investigational human IgG2 kappa monoclonal antibody $(\mathrm{mAb})$ that selectively binds to PDGFR $\alpha$ with a high degree of specificity, without crossreacting with PDGFR $\beta$ [6]. Antibody targeting of this receptor is designed to allow for specific inhibition of the PDGFR $\alpha$ pathway without affecting PDGFR $\beta$ signaling, which has the potential for an improved toxicity profile compared with less specific small molecule inhibitors such as imatinib [7, 8]. We report the results of the first-inhuman clinical study of MEDI-575 in adults with advanced solid tumors.

The primary objective of this study was to determine safety, maximum tolerated dose (MTD), and/or optimal biologic dose of MEDI-575 in adults with advanced solid tumors refractory to standard therapy or for which no standard therapy exists. Secondary objectives were assessment of the pharmacokinetic (PK) profile, immunogenicity, and antitumor activity of MEDI-575. Exploratory pharmacodynamic analysis included determination of levels of selected circulating soluble proteins (e.g., PDGF-AA).

\section{Methods}

Study design

This phase I, multicenter, open-label, single-arm, dose escalation study was conducted at five sites in the USA between January 2009 and April 2012 (ClinicalTrials.gov identifier: NCT00816400). Up to 42 patients [five cohorts of $3,6,9,12$, or $15 \mathrm{mg} / \mathrm{kg}$ dosed once weekly (QW) and two cohorts of 25 or $35 \mathrm{mg} / \mathrm{kg}$ dosed once every 3 weeks (Q3W) of 3-6 patients each] were planned for the dose escalation phase. Twelve patients were planned for inclusion in the dose expansion phase at doses determined from cohorts 1 through 7, with six patients treated on the QW dosing schedule and six patients treated on the Q3W dosing schedule. Upon review of the dose escalation data, patients in the dose expansion phase received either $9 \mathrm{mg} / \mathrm{kg}$ QW or $25 \mathrm{mg} / \mathrm{kg}$ Q3W.

\section{Patients}

Patients were eligible for study inclusion if they were aged $\geq 18$ years, had a histologically confirmed advanced solid tumor refractory to standard therapy or for which no standard therapy exists, had a life expectancy $\geq 12$ weeks, had a Karnofsky performance status $\geq 60$, and had adequate hematologic, kidney, and liver function. Patients in the dose expansion phase were limited to those with one of the following advanced solid tumors: non-small cell lung cancer (NSCLC), glioblastoma multiforme, ovarian cancer, or synovial sarcoma.

Key exclusion criteria included any prior anti-PDGF or PDGFR mAb therapy, concurrent or recent (within 4 weeks for chemotherapy or investigational therapy or within 6 weeks for biologic or immunologic therapies) standard or investigational cancer treatment, major surgery within 4 weeks of initiating MEDI-575, significant active infection requiring treatment, and use of systemic immunosuppressive steroid therapy. Prior radiation therapy was allowed, provided that exposure did not exceed an area of $25 \%$ of marrow space, and toxicities from previous cancer therapies must have recovered to grade $<2$.

\section{Dose escalation}

The starting dose of MEDI-575 was based on non-clinical PK, pharmacodynamics, and toxicology studies in cynomolgus monkeys [9]. Cohorts 1 through 5 received MEDI575 QW as a 60-min intravenous (IV) infusion dosed at 3, $6,9,12$, or $15 \mathrm{mg} / \mathrm{kg}$ on days 1,8 , and 15 of each 21 -day treatment cycle until occurrence of unacceptable toxicity, documentation of disease progression, or other reasons for patient withdrawal. Cohort 1 received MEDI-575 $0.5 \mathrm{mg} /$ $\mathrm{kg} 1$ week before the first $3-\mathrm{mg} / \mathrm{kg}$ dose to determine PK and pharmacodynamics under unsaturated conditions. If MTD was not reached at $15 \mathrm{mg} / \mathrm{kg}$, cohorts 6 and 7 were planned to evaluate MEDI-575 dosed at 25 and $35 \mathrm{mg} / \mathrm{kg}$ Q3W as 90-min IV infusions until the occurrence of toxicity or disease progression.

For cycle 2 and beyond, it was permissible to delay a dose for up to 7 days based on the occurrence of clinically significant grade 2 events or first occurrences of grade 3 or 4 events, but three doses were required to complete each cycle. Discontinuation was required if grade $\geq 2$ toxicities did not improve to grade $\leq 1$ within 7 days of onset, if grade 3 or 4 toxicities occurred with no clinical benefit from MEDI-575, or upon second occurrence of grade 3 or 4 toxicities.

\section{Assessments}

Safety was assessed after the first dose through 30 days after the last dose. MEDI-575 concentrations in serum were measured with a competitive electrochemiluminescence (ECL) assay using the Meso Scale Discovery ${ }^{\circledR}$ platform. PDGF-AA protein in human plasma was quantified using the Milliplex ${ }^{\mathrm{TM}}$ MAP Human Cytokine/Chemokine Kit (Millipore Corporation, Billerica, MA) and Luminex ${ }^{\circledR}$ xMAP technology platform (Luminex Corp., Austin, TX). An ECL-based bridging immunoassay, using a Meso Scale Discovery ${ }^{\circledR}$ platform, was used for the qualitative 
determination of antidrug antibodies against MEDI-575 in human serum. Assessment of antitumor activity included physical examination and radiography. Tumor measurements and assessments, which were based on Response Evaluation Criteria in Solid Tumors guidelines version 1.0 (RECIST), were repeated at least 4 weeks after initial documentation of a complete or partial response.

\section{Statistical analyses}

The safety population, used for the evaluation of baseline characteristics and safety, included all patients who received $\geq 1$ dose of MEDI-575. The efficacy-evaluable population included patients who received $\geq 1$ dose of MEDI-575 and had at least one tumor assessment after dosing. The MTD-evaluable population included patients who received at least one full cycle of MEDI-575 and either experienced a dose-limiting toxicity (DLT) or completed the safety follow-up through the DLT evaluation period [28 days (cohort 1) or 21 days (cohorts 2-7)] after first dose of MEDI-575.

Continuous and categorical variables for all reported outcomes were summarized by descriptive methods. Missing data were not imputed. Time to event data, including time to progression (TTP), progression-free survival (PFS), and overall survival (OS), were evaluated using KaplanMeier methods.

Pharmacokinetic parameters were estimated by noncompartmental analysis approach using WinNonlin Professional [version 5.2; Pharsight (Certara), Sunnyvale, CA]. Peak (maximum) concentration $\left(C_{\max }\right)$, time to peak concentration $\left(T_{\max }\right)$, trough serum concentration $\left(C_{\text {trough }}\right)$, and area under the concentration-time curve over the dosing interval $\left(\mathrm{AUC}_{\tau}\right)$ were determined after the first dose. Steady-state PK parameters, including peak concentration $\left(C_{\text {max,ss }}\right)$ and trough concentration $\left(C_{\text {trough,ss }}\right)$, were also estimated. The relationship between PK and pharmacodynamics was evaluated using a nonlinear mixed-effects model approach using NONMEM software (version 7).

\section{Results}

A total of 35 patients participated in the study. In the dose escalation phase, 7 cohorts $(5$ dosed QW and 2 dosed Q3W) received MEDI-575 QW $(n=17)$ or Q3W $(n=6)$, with doses ranging from 3 to $15 \mathrm{mg} / \mathrm{kg} \mathrm{QW}$ or 25 to $35 \mathrm{mg} / \mathrm{kg}$ Q3W (Fig. 1). The dose expansion phase included 12 patients at $9 \mathrm{mg} / \mathrm{kg}$ QW $(n=6)$ or $25 \mathrm{mg} /$ $\mathrm{kg}$ Q3W $(n=6)$. Overall, the patient population was predominantly white (89\%), with a median age of 65 years, baseline Karnofsky performance status of $\geq 80$ in $92 \%$, and with NSCLC and colon cancer as the most common malignancies (31 and $29 \%$, respectively, Table 1). All patients had stage III $(9 \%)$ or IV $(91 \%)$ disease at study entry and had received a median of six prior systemic cancer treatments.

The median number of treatment cycles was 2 (range 1-36) across dose groups, and the median number of MEDI-575 doses received was 6 when given QW (range 1-107) and 2 when given Q3W (range 1-8).

\section{Safety}

No DLTs were observed and the MTD was not reached for either the QW or Q3W schedules. Results showed that $C_{\max }$ levels of MEDI-575 above $150 \mu \mathrm{g} / \mathrm{mL}$ (optimal biologic concentration) were reached, starting at doses of at least $6 \mathrm{mg} / \mathrm{kg}$. Based on emerging PK-pharmacodynamic analyses, a dose of $9 \mathrm{mg} / \mathrm{kg} \mathrm{QW}$ and $25 \mathrm{mg} / \mathrm{kg}$ Q3W were expanded, and no DLTs were noted in patients receiving either of these doses.

Adverse events were reported in all 35 patients. The most frequently reported AEs were fatigue (54\%), nausea (34\%), vomiting (31\%), decreased appetite (26\%), dyspnea (26\%), abdominal pain, hypokalemia, insomnia, and muscle spasm ( $23 \%$ each), constipation (20\%), and dehydration and diarrhea (17\% each). All treatment-related AEs by severity are presented in Table 2 .

Overall, a total of 84 treatment-related AEs were reported across 24 patients: $50(60 \%)$ grade 1 events in 13 patients (including 1 patient at $9 \mathrm{mg} / \mathrm{kg} \mathrm{QW}$ with peripheral edema); 28 (33\%) grade 2 events in 7 patients; 5 (6\%) grade 3 events (including 1 patient with hypokalemia at $9 \mathrm{mg} / \mathrm{kg}$ QW, 1 patient with fatigue and 2 with hypokalemia at $25 \mathrm{mg} / \mathrm{kg} \mathrm{Q} 3 \mathrm{~W})$; and 1 (1\%) grade 4 event of pulmonary embolism at $9 \mathrm{mg} / \mathrm{kg} \mathrm{QW}$. The most frequently reported treatment-related AEs were fatigue (reported in 7 patients in the 3 to $12 \mathrm{mg} / \mathrm{kg}$ QW groups; 5 patients in the 25 and $35 \mathrm{mg} / \mathrm{kg}$ Q3W groups) and nausea (reported in 4 patients in the 3 to $15 \mathrm{mg} / \mathrm{kg}$ QW groups; 4 patients in the 25 and $35 \mathrm{mg} / \mathrm{kg}$ Q3W groups).

Eight of 35 patients $(23 \%)$ discontinued MEDI-575 due to an $\mathrm{AE} ; 1$ patient at the $6-\mathrm{mg} / \mathrm{kg}$ dose with diarrhea, 4 patients at the $9-\mathrm{mg} / \mathrm{kg}$ dose ( 5 events: central nervous system metastasis, pericardial effusion, cerebrovascular accident, increased alkaline phosphatase, and femur fracture), and 3 patients at the $25-\mathrm{mg} / \mathrm{kg}$ dose [ 4 events: dyspnea, hypercalcemia ( 2 events in 1 patient), and NSCLC]. No discontinuations were considered related to MEDI-575.

A total of 23 serious AEs were reported in 13 of 35 (37\%) patients (Table 3). One serious AE was considered treatment-related; the aforementioned pulmonary embolism in a patient with NSCLC treated at the $9-\mathrm{mg} / \mathrm{kg}$ QW dose level. The event was reported 14 days after the first dose of MEDI-575 and caused an interruption in dosing. 


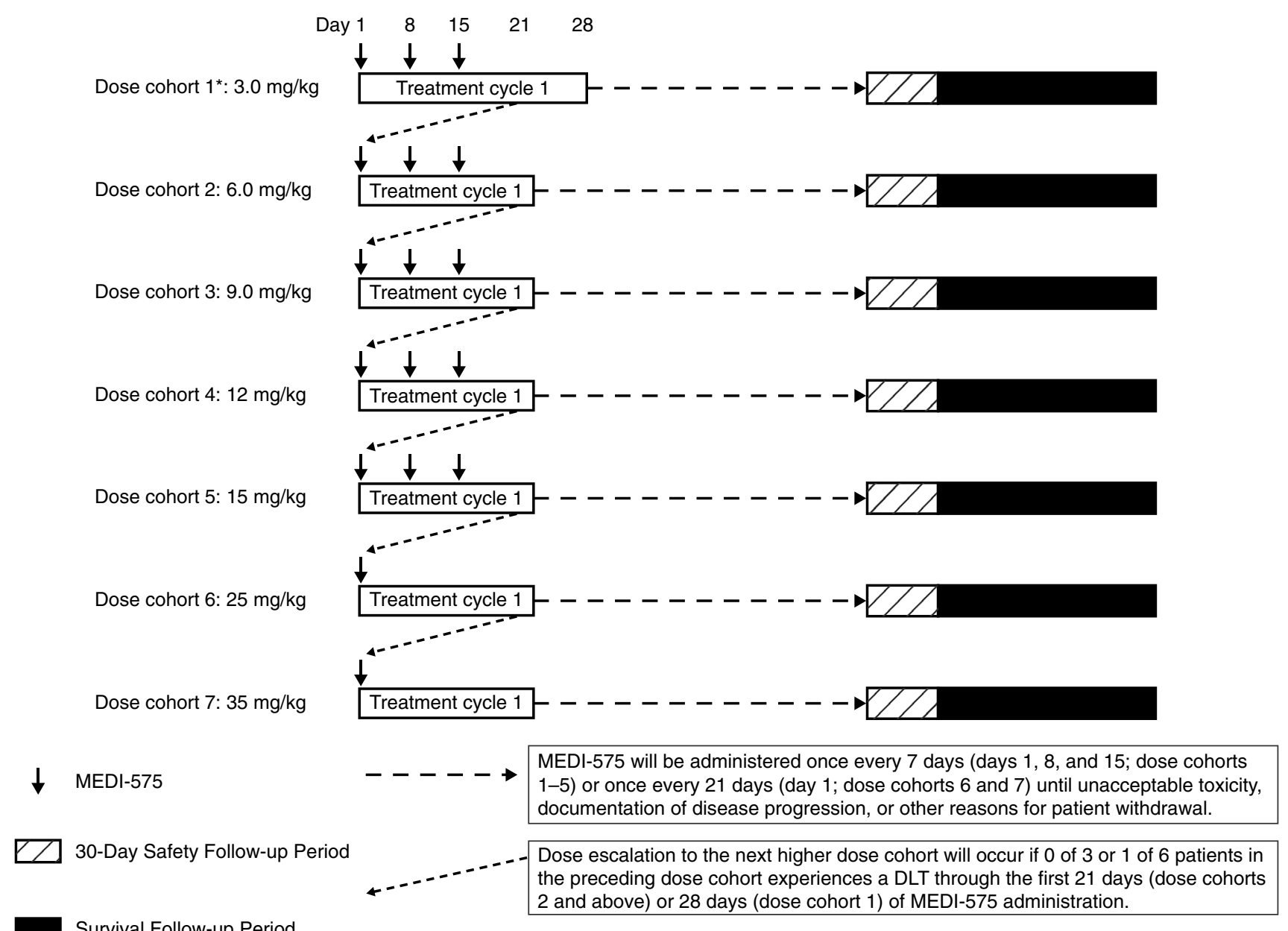

Fig. 1 Dose escalation study design. The dose expansion phase included two additional cohorts dosed at either $9 \mathrm{mg} / \mathrm{kg}$ weekly or $25 \mathrm{mg} / \mathrm{kg}$ every 3 weeks. *Patients enrolled in dose cohort 1 received

The patient recovered with sequelae and received a total of eight doses before discontinuing the study due to disease progression. By the end of the study, 29 deaths had occurred, 3 during treatment. All deaths were attributable to disease progression.

\section{Pharmacokinetics}

The mean serum concentration-time profiles of MEDI575 are shown in Fig. 2a and estimated PK parameters in Table 4. Mean serum concentrations increased with an increase in MEDI-575 dose following both QW and Q3W dosing regimens. After the first QW dose, the increase in mean $\mathrm{AUC}_{\tau}$ (days 1-8) was more than dose proportional, reflecting nonlinearity in the PK of MEDI575. However, mean $\mathrm{AUC}_{\tau}$ (days 1-21) increased in an approximately dose-proportional manner after the first Q3W dose of 25 and $35 \mathrm{mg} / \mathrm{kg}$, reflecting saturation of nonlinear elimination pathways. The $C_{\max }$ after the first a single lead-in dose of MEDI-575 at $0.5 \mathrm{mg} / \mathrm{kg}$ on day 1 (7 days prior to receipt of the first dose of MEDI-575 $3 \mathrm{mg} / \mathrm{kg}$ on day 8)

dose increased in an approximately dose-proportional manner over the dose range of $0.5 / 3 \mathrm{mg} / \mathrm{kg}$ to $35 \mathrm{mg} / \mathrm{kg}$. At steady state, the PK exposure increased in an approximately dose-proportional manner over the dose range of $3 \mathrm{mg} / \mathrm{kg}$ to $35 \mathrm{mg} / \mathrm{kg}$. The steady-state PK exposure was similar between the 12 and $15-\mathrm{mg} / \mathrm{kg}$ QW cohorts, likely due to higher mean body weight for patients in the $12-\mathrm{mg} / \mathrm{kg}$ cohort compared with the $15-\mathrm{mg} / \mathrm{kg}$ cohort (77 vs. $68 \mathrm{~kg}$ ). The mean linear clearance and steadystate volume of distribution were $168 \mathrm{~mL} /$ day and $4.42 \mathrm{~L}$, respectively. The concentration corresponding to half maximum capacity $\left(\mathrm{K}_{\mathrm{M}}\right)$ for nonlinear clearance was $8.64 \mu \mathrm{g} / \mathrm{mL}$.

Pharmacodynamics

A dose-dependent increase in plasma concentrations of PDGF-AA ligand was observed following IV administration of MEDI-575 QW and Q3W, consistent with 
Table 1 Baseline demographic and clinical characteristics

\begin{tabular}{|c|c|c|c|}
\hline Parameter, $n$ & QW cohorts $1-5(n=23)$ & Q3W cohorts 6 and $7(n=12)$ & Total $(n=35)$ \\
\hline Median age, years (range) & $66.0(39-83)$ & $60.0(50-78)$ & $65.0(39-83)$ \\
\hline \multicolumn{4}{|l|}{ Sex, $n(\%)$} \\
\hline Male & $11(48)$ & $8(67)$ & $19(54)$ \\
\hline Female & $12(52)$ & $4(33)$ & $16(46)$ \\
\hline \multicolumn{4}{|l|}{ Race, $n(\%)$} \\
\hline White & $20(87)$ & $11(92)$ & $31(89)$ \\
\hline Black & $2(9)$ & 0 & $2(6)$ \\
\hline Asian & $1(4)$ & $1(8)$ & $2(6)$ \\
\hline \multicolumn{4}{|l|}{ Ethnicity, $n(\%)$} \\
\hline Hispanic or Latino & $3(13)$ & 0 & $3(9)$ \\
\hline \multicolumn{4}{|l|}{ Karnofsky performance status, $n(\%)$} \\
\hline 60 & 0 & $1(8)$ & $1(3)$ \\
\hline 70 & $2(9)$ & 0 & $2(6)$ \\
\hline 80 & $8(35)$ & $4(33)$ & $12(34)$ \\
\hline 90 & $12(52)$ & $7(58)$ & $19(54)$ \\
\hline 100 & $1(4)$ & 0 & $1(3)$ \\
\hline \multicolumn{4}{|l|}{ Primary tumor type, $n(\%)$} \\
\hline Breast adenocarcinoma & $1(4)$ & 0 & $1(3)$ \\
\hline Colon & $6(26)$ & $4(33)$ & $10(29)$ \\
\hline Endometrial & $1(4)$ & 0 & $1(3)$ \\
\hline Non-small cell lung & $6(26)$ & $5(42)$ & $11(31)$ \\
\hline Ovarian & $2(9)$ & $1(8)$ & $3(9)$ \\
\hline Prostate & $2(9)$ & $1(8)$ & $3(9)$ \\
\hline Other & $5(22)$ & $1(8)$ & $6(17)$ \\
\hline \multicolumn{4}{|l|}{ Stage at entry, $n(\%)$} \\
\hline III & $3(13)$ & 0 & $3(9)$ \\
\hline IV & $20(87)$ & $12(100)$ & $32(91)$ \\
\hline Median number of prior systemic treatments (range) & $7.0(2-16)$ & $5.0(2-13)$ & $6.0(2-16)$ \\
\hline
\end{tabular}

$Q W$ weekly, $Q 3 W$ every 3 weeks

the dose-dependent inhibition of PDGF-AA binding to PDGFR $\alpha$ and subsequent target-mediated degradation (Fig. 2b). Following the lead-in dose of $0.5 \mathrm{mg} / \mathrm{kg}$, PDGFAA levels increased up to 2 days, followed by a decrease to baseline levels on day 7 due to a decline in MEDI-575 concentrations to levels below the limit of quantification (BLQ). At doses higher than $3 \mathrm{mg} / \mathrm{kg}$, the increase in plasma PDGF-AA ligand concentrations plateaued within approximately 2 days and the concentrations are sustained throughout the dosing interval. The PK-pharmacodynamic analysis was performed to describe the relationship between MEDI-575 concentrations and PDGF-AA ligand. The half-maximal concentration $\left(\mathrm{IC}_{50}\right.$ ) of MEDI-575 for PDGF-AA accumulation was approximately $1.5 \mu \mathrm{g} / \mathrm{mL}$. Based on the mean $\mathrm{IC}_{50}$, greater than $99 \%$ saturation of PDGFR $\alpha$ is expected at about $150 \mu \mathrm{g} / \mathrm{mL}$ of MEDI-575, which can be achieved with MEDI-575 $9 \mathrm{mg} / \mathrm{kg}$ QW and $25 \mathrm{mg} / \mathrm{kg}$ Q3W.
Immunogenicity

Antidrug antibodies were detected in two patients in the $25-\mathrm{mg} / \mathrm{kg}$ Q3W cohort prior to the first administration of MEDI-575 on day 1 and were deemed false-positive results. Following the administration of MEDI-575 QW, antidrug antibodies were detected in one patient 30 days post-treatment after receiving one dose of MEDI-575 at $0.5 \mathrm{mg} / \mathrm{kg}$ followed by six doses at $3 \mathrm{mg} / \mathrm{kg}$. No adverse events associated with the antibodies were observed. Low antidrug antibody titers $(\leq 39-78)$ were observed. No obvious impact of antidrug antibodies on the PK and pharmacodynamic profiles of MEDI-575 were noted.

Antitumor activity

No objective responses based on RECIST (v1.0) were documented. The best overall response of stable disease (SD) 
Table 2 All treatment-related adverse events by dose level

\begin{tabular}{|c|c|c|c|c|c|c|c|c|c|}
\hline \multirow[t]{2}{*}{ Event, $n$} & \multicolumn{6}{|c|}{ MEDI-575 dose QW } & \multicolumn{3}{|c|}{ MEDI-575 dose Q3W } \\
\hline & $\begin{array}{l}3 \mathrm{mg} / \mathrm{kg} \\
(n=3)\end{array}$ & $\begin{array}{l}6 \mathrm{mg} / \mathrm{kg} \\
(n=3)\end{array}$ & $\begin{array}{l}9 \mathrm{mg} / \mathrm{kg} \\
(n=11)\end{array}$ & $\begin{array}{l}12 \mathrm{mg} / \mathrm{kg} \\
(n=3)\end{array}$ & $\begin{array}{l}15 \mathrm{mg} / \mathrm{kg} \\
(n=3)\end{array}$ & $\begin{array}{l}\text { Total } \\
(n=23)\end{array}$ & $\begin{array}{l}25 \mathrm{mg} / \mathrm{kg} \\
(n=9)\end{array}$ & $\begin{array}{l}35 \mathrm{mg} / \mathrm{kg} \\
(n=3)\end{array}$ & $\begin{array}{l}\text { Total } \\
(n=12)\end{array}$ \\
\hline Anemia & - & - & 1 & 1 & - & 2 & 2 & - & 2 \\
\hline Asthenia & - & - & - & - & - & - & 1 & - & 1 \\
\hline Blood creatinine increased & - & - & - & - & - & - & - & 1 & 1 \\
\hline Chills & 1 & - & 1 & - & - & 2 & - & - & - \\
\hline Decreased appetite & 1 & - & - & - & - & 2 & 1 & 1 & 2 \\
\hline Dehydration & - & - & - & - & - & - & 1 & 1 & 2 \\
\hline Diarrhea & - & - & 1 & - & - & 1 & - & 1 & 1 \\
\hline Dry mouth & - & - & - & - & - & - & 1 & - & 1 \\
\hline Dry skin & - & - & - & - & - & - & - & 1 & 1 \\
\hline Dyspnea & - & - & 1 & - & - & 1 & - & - & - \\
\hline Ear discomfort & - & - & - & 1 & - & 1 & - & - & - \\
\hline Fatigue & 2 & 1 & 3 & 1 & - & 7 & $3 *$ & 2 & $5^{*}$ \\
\hline Feeling abnormal & - & - & - & 1 & - & 1 & - & - & - \\
\hline Flushing & - & - & - & - & - & - & - & 1 & 1 \\
\hline Herpes zoster & - & - & - & - & - & - & 1 & - & 1 \\
\hline Hypokalemia & - & - & $3 *$ & - & - & $3 *$ & $2^{\dagger}$ & - & $2^{\dagger}$ \\
\hline Hypomagnesemia & - & - & 1 & - & - & 1 & 1 & 1 & 2 \\
\hline Hypotension & - & - & - & - & - & - & 1 & - & 1 \\
\hline Infusion reaction & 1 & - & - & - & - & 1 & - & - & - \\
\hline Insomnia & - & - & - & 1 & - & 1 & - & - & - \\
\hline Muscle spasms & - & - & 1 & 2 & - & 3 & 1 & - & 1 \\
\hline Myalgia & 1 & 1 & - & - & - & 2 & - & - & - \\
\hline Nausea & 2 & - & 1 & 1 & - & 4 & 3 & 1 & 4 \\
\hline Peripheral edema & - & - & 1 & - & - & 1 & - & - & - \\
\hline Pulmonary embolism & - & - & $1^{\ddagger}$ & - & - & $1^{\ddagger}$ & - & - & - \\
\hline Thrombocytopenia & - & - & - & - & - & - & 1 & - & 1 \\
\hline Urine urobilinogen increased & - & - & - & - & - & - & 1 & - & 1 \\
\hline Vomiting & 1 & - & 1 & - & - & 2 & 1 & - & 1 \\
\hline
\end{tabular}

$Q W$ weekly; $Q 3 W$ every 3 weeks

$* 1$ grade 3 event

$\dagger 2$ grade 3 events

$\ddagger 1$ grade 4 event

occurred in 9 of 29 evaluable patients (31\%), including 6 patients in the QW cohorts ( 1 of 3 at $3 \mathrm{mg} / \mathrm{kg} ; 1$ of 3 at $6 \mathrm{mg} / \mathrm{kg} ; 2$ of 7 at $9 \mathrm{mg} / \mathrm{kg}$; and 2 of 3 at $15 \mathrm{mg} / \mathrm{kg}$ ) and 3 patients in the Q3W cohorts ( 3 of 7 at $25 \mathrm{mg} / \mathrm{kg}$ ). Overall, for the 29 evaluable patients, median TTP and PFS were 1.4 months (95\% CI 1.4, 1.5 months) and median OS was 8.4 months (95\% CI 3.6, 10.5 months). Median TTP and PFS were identical between the combined QW and Q3W cohorts, in whom the median OS was 7.4 months (95\% CI 3.6, 19.4 months) and 8.6 months (95\% CI 2.4, 10.5 months), respectively.

\section{Discussion}

In this phase I study of MEDI-575 in patients with previously treated advanced solid tumors, dosing up to $15 \mathrm{mg} / \mathrm{kg}$ QW and $35 \mathrm{mg} / \mathrm{kg}$ Q3W resulted in treatment-related AEs that were predominantly grade 1 or 2 in severity. The MTD was not reached. Clinical PK and pharmacodynamic analyses identified more than $99 \%$ PDGFR $\alpha$ saturation at $150 \mu \mathrm{g} / \mathrm{mL}$ of MEDI-575, and there was minimal evidence of immunogenicity per detectable ADAs. Stable disease was the best tumor response, with no patients achieving an objective response. 
Table 3 All serious adverse events by dose level

\begin{tabular}{|c|c|c|c|c|c|c|c|c|c|}
\hline \multirow[t]{2}{*}{ Event, $n$} & \multicolumn{6}{|c|}{ MEDI-575 dose QW } & \multicolumn{3}{|c|}{ MEDI-575 dose Q3W } \\
\hline & $\begin{array}{l}3 \mathrm{mg} / \mathrm{kg} \\
\mathrm{QW}(n=3)\end{array}$ & $\begin{array}{l}6 \mathrm{mg} / \mathrm{kg} \\
\mathrm{QW}(n=3)\end{array}$ & $\begin{array}{l}9 \mathrm{mg} / \mathrm{kg} \mathrm{QW} \\
(n=11)\end{array}$ & $\begin{array}{l}12 \mathrm{mg} / \mathrm{kg} \\
\mathrm{QW}(n=3)\end{array}$ & $\begin{array}{l}15 \mathrm{mg} / \mathrm{kg} \\
\mathrm{QW}(n=3)\end{array}$ & $\begin{array}{l}\text { Total QW } \\
(n=23)\end{array}$ & $\begin{array}{l}25 \mathrm{mg} / \mathrm{kg} \\
\mathrm{Q} 3 \mathrm{~W}(n=9)\end{array}$ & $\begin{array}{l}35 \mathrm{mg} / \mathrm{kg} \\
\mathrm{Q} 3 \mathrm{~W}(n=3)\end{array}$ & $\begin{array}{l}\text { Total Q3W } \\
(n=12)\end{array}$ \\
\hline Total number of events & - & 1 & 15 & - & - & 16 & 2 & 5 & 7 \\
\hline $\begin{array}{l}\text { Total patients reporting } \\
\geq 1 \text { event }\end{array}$ & - & 1 & 8 & - & - & 9 & 2 & 2 & 4 \\
\hline Pericardial effusion & - & - & 1 & - & - & 1 & - & - & - \\
\hline Abdominal pain & - & - & 1 & - & - & 1 & - & - & - \\
\hline Gastritis & - & - & - & - & - & - & - & 1 & 1 \\
\hline Pancreatitis & - & 1 & - & - & - & 1 & - & - & - \\
\hline Multi-organ failure & - & - & - & - & - & - & - & 1 & 1 \\
\hline Non-cardiac chest pain & - & - & 1 & - & - & 1 & - & - & - \\
\hline Cellulitis & - & - & - & - & - & - & - & 1 & 1 \\
\hline Femoral neck fracture & - & - & 1 & - & - & 1 & - & - & - \\
\hline Hyperglycemia & - & - & 1 & - & - & 1 & - & - & - \\
\hline Fistula & - & - & - & - & - & - & - & 1 & 1 \\
\hline CNS metastases & - & - & 1 & - & - & 1 & - & - & - \\
\hline NSCLC & - & - & 3 & - & - & 3 & 1 & - & 1 \\
\hline $\begin{array}{l}\text { Cerebrovascular acci- } \\
\text { dent }\end{array}$ & - & - & 1 & - & - & 1 & - & - & - \\
\hline Convulsion & - & - & - & - & - & - & - & 1 & 1 \\
\hline Confusional state & - & - & 1 & - & - & 1 & - & - & - \\
\hline Dyspnea & - & - & - & - & - & - & 1 & - & 1 \\
\hline Pleural effusion & - & - & 1 & - & - & 1 & - & - & - \\
\hline Pneumothorax & - & - & 2 & - & - & 2 & - & - & - \\
\hline Pulmonary embolism & - & - & 1 & - & - & 1 & - & - & - \\
\hline
\end{tabular}

$C N S$ central nervous system, $N S C L C$ non-small cell lung cancer, $Q W$ weekly, $Q 3 W$ every 3 weeks

MEDI-575 is a human mAb that selectively binds to PDGFR $\alpha$ with high affinity, inhibiting signaling from PDGFR $\alpha$ on cancer cells and supportive stroma without inhibiting PDGFR $\beta$ [6]. This mechanism has important implications from a safety and tolerability standpoint, as it is recognized that inhibitors targeting both PDGFR $\alpha$ and PDGFR $\beta$ can lead to extravascular fluid accumulation, likely a consequence of inhibiting PDGFR $\beta$ [7]. With MEDI-575, there was only one report of treatment-related grade 1 peripheral edema at the $9-\mathrm{mg} / \mathrm{kg}$ dose level. Most treatment-related AEs did not exceed grade 2, the exceptions being 3 reports of grade 3 hypokalemia as well as individual reports of grade 3 fatigue and grade 4 pulmonary thromboembolism. The overall favorable safety profile across all MEDI-575 doses is noteworthy, especially considering the number of prior treatment regimens patients in this study population received.

Additional data to support the safety and tolerability of targeting PDGFR $\alpha$ in advanced malignancies are available from a phase 1 study of an anti-PDGFR $\alpha \operatorname{IgG} 1 \mathrm{mAb}$, olaratumab (formerly IMC-3G3) [10]. In that study, patients received 1 of 3 doses of antibody $(4,8$, or $16 \mathrm{mg} / \mathrm{kg}) \mathrm{QW}$ or 15 or $20 \mathrm{mg} / \mathrm{kg}$ once every 2 weeks. No DLTs or grade $\geq 3$ AEs were observed; however, as in our study, no objective tumor responses were reported [11]. To date, for both MEDI-575 and olaratumab, preclinical observations supporting antitumor activity against lung tumors $[6,12]$ have not translated into advances in the clinic.

Overall, MEDI-575 exhibited nonlinear PK over the dose range of $0.5-35 \mathrm{mg} / \mathrm{kg}$, which is consistent with receptor-mediated clearance with saturation of PDGFR $\alpha$ at doses of $3 \mathrm{mg} / \mathrm{kg}$ or higher. The systemic linear clearance $(\approx 170 \mathrm{~mL} /$ day $)$ and small steady-state volume of distribution $(\approx 4 \mathrm{~L})$ are in line with other mAbs [13-15]. MEDI575 binding with PDGFR $\alpha$ resulted in a dose-dependent increase in PDGF-AA ligand with plateau levels within 2 days at doses $\geq 3 \mathrm{mg} / \mathrm{kg}$ and the concentrations are sustained throughout the dosing interval. Complete target saturation is expected at about $150 \mu \mathrm{g} / \mathrm{mL}$ of MEDI-575. A low incidence of immunogenicity was observed, with no resultant impact on MEDI-575 PK and pharmacodynamic parameters.

The results of this study should be considered in the context of several limitations inherent to most open-label 
Fig. 2 Pharmacokinetic and pharmacodynamic effects of MEDI-575. Mean a MEDI575 serum concentration-time profiles and $\mathbf{b}$ PDGF-AA plasma concentration-time profiles following weekly and every 3 week dosing regimens of MEDI-575. PDGF plateletderived growth factor, $Q W$ once weekly; $Q 3 W$ every 3 weeks
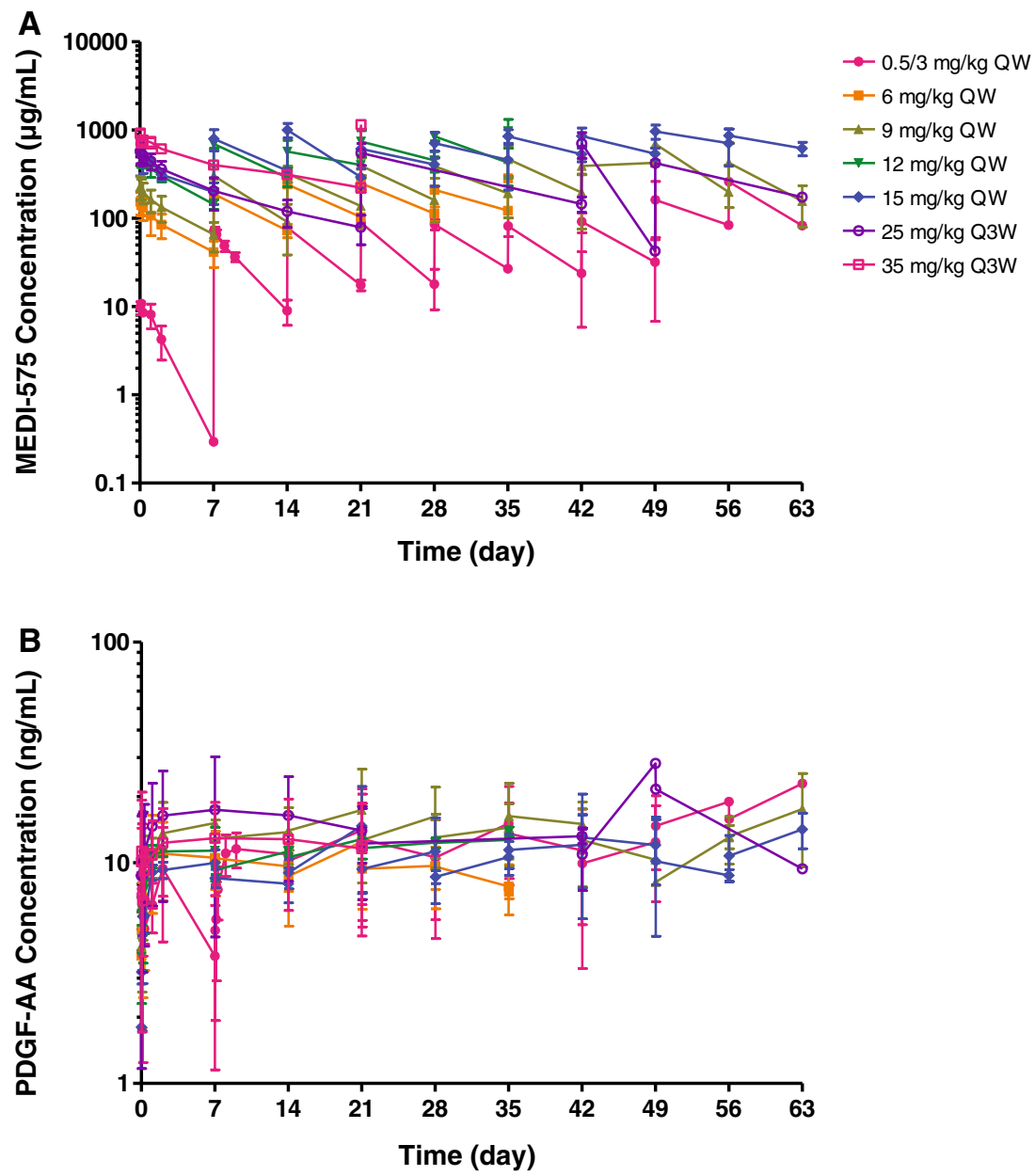

Table 4 Mean pharmacokinetic parameters of MEDI-575

\begin{tabular}{|c|c|c|c|c|c|c|}
\hline Dose $(\mathrm{mg} / \mathrm{kg})$ & $T_{\max }$ (day) & $C_{\max }(\mu \mathrm{g} / \mathrm{mL})$ & $C_{\text {trough }}(\mu \mathrm{g} / \mathrm{mL})$ & $\mathrm{AUC}_{\tau}(\mu \mathrm{g}$ day $/ \mathrm{mL})$ & $C_{\max , \mathrm{ss}}(\mu \mathrm{g} / \mathrm{mL})$ & $C_{\text {trough,ss }}(\mu \mathrm{g} / \mathrm{mL})$ \\
\hline 0.5 & $0.103(48.3)$ & $10.9(4.7)$ & BLQ (ND) & $25.3(30.4)$ & ND (ND) & $\mathrm{ND}(\mathrm{ND})$ \\
\hline $3 \mathrm{QW}$ & $0.076(71.8)$ & $72.6(9.6)$ & $8.97(31.7)$ & $201(6.2)$ & $104(20.4)$ & $35.5(44.5)$ \\
\hline $6 \mathrm{QW}$ & $0.048(6.6)$ & $154(29.2)$ & $41.5(33.2)$ & $524(31.7)$ & $287(4.9)$ & $144(25.6)$ \\
\hline $9 \mathrm{QW}$ & $0.104(71.0)$ & $239(29.0)$ & $63.1(39.3)$ & $874(46.7)$ & $387(39.1)$ & $202(97.1)$ \\
\hline $12 \mathrm{QW}$ & $0.130(109.3)$ & $590(21.1)$ & $144(12.5)$ & $1,870(14.8)$ & $970(36.0)$ & $415(46.5)$ \\
\hline $15 \mathrm{QW}$ & $0.107(35.8)$ & $632(3.2)$ & $199(27.8)$ & $2,080(9.8)$ & $856(3.3)$ & 266 (ND) \\
\hline $25 \mathrm{Q} 3 \mathrm{~W}$ & $0.154(75.5)$ & $590(24.4)$ & $74.6(48.8)$ & $4,200(20.9)$ & $602(35.8)$ & $117(47.8)$ \\
\hline $35 \mathrm{Q} 3 \mathrm{~W}$ & $0.064(2.2)$ & $918(12.1)$ & $223(11.3)$ & $8,340(4.5)$ & $1,160(11.8)$ & 159 (ND) \\
\hline
\end{tabular}

Values are presented as mean (standard deviation)

$A U C_{\tau}$ area under the concentration-time curve, $B L Q$ below the limit of quantification, $C_{\text {max }}$ peak concentration, $C_{\text {max ss }}$ peak concentration at steady state, $C_{\text {trough }}$ trough serum concentration, $C_{\text {trough,ss }}$ trough concentration at steady state, $N D$ not determined, $Q W$ weekly, $Q 3 W$ every 3 weeks, $T_{\max }$ time to peak concentration

(non-blinded) phase I studies, which are typically conducted in a small number of patients who have received multiple previous treatments and have refractory advanced disease. Most of the cohorts in this study were limited to three patients each.
In conclusion, MEDI-575 produced a favorable safety profile (including no DLTs) when administered QW or Q3W, but with no evidence of antitumor activity among adults with unselected refractory solid tumors who underwent a median of six prior systemic cancer treatments. The 
next step would be to identify tumors that selectively activate the pathway to determine whether blocking the signaling of the pathway with MEDI-575 may have a therapeutic effect.

Acknowledgments The authors thank all patients who consented to participate in this study, the study coordinators who facilitated the conduct of the study, Dr. Robert Jotte of Rocky Mountain Cancer Center, Denver, CO, who participated as a principal investigator, Dr. Susan Perez (MedImmune) for clinical study support, Amy Schneider (MedImmune) for performing the PDGF-AA analysis, and Koustubh Ranade (Medimmune) for reviewing the manuscript. We also acknowledge Diana Swanson, PhD (MedImmune), and Amy Zannikos, PharmD (Peloton Advantage, Parsippany, NJ), for medical writing and editorial support, which were funded by MedImmune.

Conflict of interest C.R.B., P.C., N.V., and H.W. received research funding for this study through their institutions. N.P. is an employee of MedImmune. S.H., M.L., and R.N. are employees of MedImmune and own stock in AstraZeneca. F.T. is a post-doctoral fellow at MedImmune.

Ethical standard The protocol for this study was reviewed and approved by the Institutional Review Board or Independent Ethics Committee of each participating center prior to study initiation. Each patient/legal representative provided written informed consent prior to the screening procedures required for study entry.

Open Access This article is distributed under the terms of the Creative Commons Attribution License which permits any use, distribution, and reproduction in any medium, provided the original author(s) and the source are credited.

\section{References}

1. Ostman A (2004) PDGF receptors-mediators of autocrine tumor growth and regulators of tumor vasculature and stroma. Cytokine Growth Factor Rev 15:275-286

2. Baccarani M, Cilloni D, Rondoni M et al (2007) The efficacy of imatinib mesylate in patients with FIP1L1-PDGFRalpha-positive hypereosinophilic syndrome. Results of a multicenter prospective study. Haematologica 92:1173-1179

3. Buitenhuis M, Verhagen LP, Cools J, Coffer PJ (2007) Molecular mechanisms underlying FIP1L1-PDGFRA-mediated myeloproliferation. Cancer Res 67:3759-3766

4. Shikada Y, Yonemitsu Y, Koga T et al (2005) Platelet-derived growth factor-AA is an essential and autocrine regulator of vascular endothelial growth factor expression in non-small cell lung carcinomas. Cancer Res 65:7241-7248

5. Tejada ML, Yu L, Dong J et al (2006) Tumor-driven paracrine platelet-derived growth factor receptor alpha signaling is a key determinant of stromal cell recruitment in a model of human lung carcinoma. Clin Cancer Res 12:2676-2688

6. Laing N, McDermott B, Wen S et al (2013) Inhibition of PDGFRalpha by MEDI-575 reduces tumor growth and stromal fibroblast content in a model of non-small cell lung cancer. Mol Pharmacol 83:1247-1256

7. Jayson GC, Parker GJ, Mullamitha S et al (2005) Blockade of platelet-derived growth factor receptor-beta by CDP860, a humanized, PEGylated di-Fab', leads to fluid accumulation and is associated with increased tumor vascularized volume. J Clin Oncol 23:973-981

8. Quintas-Cardama A, Kantarjian H, O'Brien S et al (2007) Pleural effusion in patients with chronic myelogenous leukemia treated with dasatinib after imatinib failure. J Clin Oncol 25:3908-3914

9. Zusmanovich M, Vainshtein I, Roskos L, Tabrizi M, Liang M (2009) A pharmacokinetic study of MEDI-575, a fully human IgG2 monoclonal antibody against platelet-derived growth factor receptor alpha, in cynomolgus monkeys following intravenous administration [poster]. Presented at the Annual Meeting and Exposition of the American Association of Pharmaceutical Scientists, Los Angeles, CA, 8-12 November 2009

10. Chiorean E, Sweeney C, Youssoufian H, Fox F, Katz T, Rowinsky E, Amato R (2008) Phase I study of IMC-3G3, an IgG1 monoclonal antibody targeting platelet-derived growth factor alpha (PDGFRa) in patients with advanced solid malignancies [abstract]. Presented at the EORTC-NCI-AACR Symposium on Molecular Targets and Cancer Therapeutics, Geneva, Switzerland, 21-24 October 2008

11. Shah GD, Loizos N, Youssoufian H, Schwartz JD, Rowinsky EK (2010) Rationale for the development of IMC-3G3, a fully human immunoglobulin $\mathrm{G}$ subclass 1 monoclonal antibody targeting the platelet-derived growth factor receptor alpha. Cancer 116:1018-1026

12. Gerber DE, Gupta P, Dellinger MT et al (2012) Stromal plateletderived growth factor receptor alpha (PDGFRalpha) provides a therapeutic target independent of tumor cell PDGFRalpha expression in lung cancer xenografts. Mol Cancer Ther 11:2473-2482

13. Azzopardi N, Lecomte T, Ternant D et al (2011) Cetuximab pharmacokinetics influences progression-free survival of metastatic colorectal cancer patients. Clin Cancer Res 17:6329-6337

14. Lu JF, Bruno R, Eppler S, Novotny W, Lum B, Gaudreault J (2008) Clinical pharmacokinetics of bevacizumab in patients with solid tumors. Cancer Chemother Pharmacol 62:779-786

15. Narwal R, Roskos LK, Robbie GJ (2013) Population Pharmacokinetics of Sifalimumab, an Investigational Anti-Interferonalpha Monoclonal Antibody, in Systemic Lupus Erythematosus. Clin Pharmacokinet 52:1017-1027 